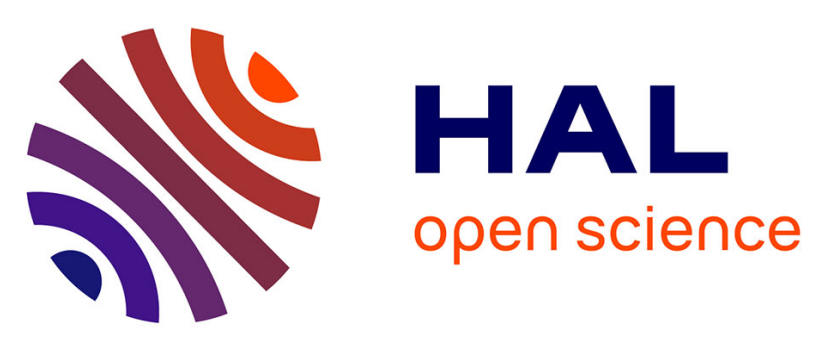

\title{
The elusive promise of universal social protection: the case of the Greek general minimum income (GMI)
}

\author{
Noëlle M Burgi, Eleni Kyramargiou
}

\section{To cite this version:}

Noëlle M Burgi, Eleni Kyramargiou. The elusive promise of universal social protection: the case of the Greek general minimum income (GMI). International Journal of Sociology and Social Policy, inPress, ahead-of-print EarlyCite, 10.1108/ijssp-11-2020-0497 . hal-03348225

\section{HAL Id: hal-03348225 \\ https://hal.science/hal-03348225}

Submitted on 24 Sep 2021

HAL is a multi-disciplinary open access archive for the deposit and dissemination of scientific research documents, whether they are published or not. The documents may come from teaching and research institutions in France or abroad, or from public or private research centers.
L'archive ouverte pluridisciplinaire HAL, est destinée au dépôt et à la diffusion de documents scientifiques de niveau recherche, publiés ou non, émanant des établissements d'enseignement et de recherche français ou étrangers, des laboratoires publics ou privés. 


\author{
Noëlle Burgi (CNRS, CESSP, École Française d'Athènes), with \\ Eleni Kyramargiou (NHRF, Institute of Historical Research (IHR)
}

\author{
The elusive promise of Universal Social Protection: \\ The case of the Greek General Minimum Income (GMI)
}

\begin{abstract}
Purpose:

The need to alleviate poverty and achieve the United Nations (UN) 2030 Sustainable Development Goals (SDGs) through Universal Social Protection (USP) mechanisms is a high priority for governments and international organisations. This paper focuses on the recent introduction of a GMI in Greece, in the context of the international diffusion of governing expertise. It examines whether the "universal" scheme being implemented constitutes a paradigm shift likely to offer solutions to the country's previous fragmented and unjust welfare system, and to problems the society has faced since the 2010s depression.
\end{abstract}

\title{
Design/methodology/approach
}

The paper uses critical grounded theory, with data gathering through iterative field observations and semi-structured interviews.

\section{Findings}

Results highlight the elusiveness of USP normative promises: rather than enhancing people's effective freedoms to act as self-determining agents, USP pushes the poor to adapt to current degraded socio-economic conditions. Participation in the shadow economy is a structural feature of USP; it is implicitly tolerated insofar as it is regarded, in the words of the World Bank, an "engine for growth". This constitutes an institutional and governance challenge for the implementation and expansion of social welfare programmes, and could compromise the 2030 SDGs Agenda.

\section{Originality/value}

While research to date has examined the "modernisation" of the Greek welfare system in a national or comparative perspective, it adds to the literature by framing the study in the field of global social policy, shedding light on the discrepancies between internationally designed mechanisms and the normative aims of USP.

Keywords: General Minimum Income, Greece, Universal Social Protection, Global Social Policy, Activation, Shadow Economy.

\section{Introduction}

Social protection institutions have long been regarded as an essential component of national sovereignty and self-determination. However, since the 1990s this view has lost credence in the face of what Bob Deacon (1997) called the "socialization of global politics" or, as Von Gliszczynski and Leisering (2016) write, the "globalization of (national) social policy". 
According to Deacon (1997, pp. 53-54), "the globalization process has shifted the locus both of social policy making and...the issues which a globalised social policy is increasingly being called upon to address... The making of national social policy is increasingly the business of supranational actors".

Global social policies refer to an emerging consensus in the 1990s and 2000s on a new development policy model informed by the "discovery" of the poor as agents of economic development rather than passive recipients of social transfers. Drawing lessons from the deleterious social and economic consequences of structural adjustment programmes (e.g. the Lost Decade in Latin America), and in response to new risks and needs arising from fundamental changes in the labour market and from ageing populations, influential international institutions engaged in an active process of social policy construction. The World Bank (WB), which is responsible for promoting economic development and reducing poverty in the world, took a leadership role in the mid-1990s (Merrien, 2013) in crafting key concepts, frameworks and instruments supporting a new "pro-poor" approach. By the mid2000s, it had acquired discursive dominance (Gliszczynski, 2015, p.45). Universality entered the global agenda first for primary education (2000), then for health coverage (2013), and finally for social protection (2015) when the International Labour Organisation (ILO) and the WB announced a "shared mission" to further the UN 2030 SDGs (ILO and WB Group, 2015). The latter seek to end poverty, hunger and inequality, improve access to health and education, tackle climate change, and much more. The Bank's commitment to the SDGs and earlier turnaround towards universality seem to represent "a complete flip around from [the previous] 'trickle down' and the 'trickle-down-plus' agenda which has that it is growth which leads to reduced poverty". The new perspective implies "that you will not get sustainable growth if inequality or poverty is too severe" (Kanbur and Vines, 2000, p. 88-91).

If we are to "do things right for the future" in response to the unprecedented "wake-up call" of the pandemic, as urged by UN Secretary-General António Guterres, we have to ask whether the "re-entry" of "universality in the development agenda" (ILO and WB Group, 2015) and the social protection policies worked out in the name of universality and poverty alleviation are indicative of a "trend" (Shriwise et al., 2020), a "post-neoliberal" era, a "paradigm" shift (Hemerijck 2012, 2018), or something else? Universalism is polysemic and the governance shift upwards does not imply uniform or even coherent (inter)national strategies. The international diffusion of governing expertise is always multidirectional, albeit asymmetrical. Expertise importers "make adaptations depending on their positions and interests" in fields of power (Dezalay and Garth, 2011). The asymmetry of power positions, resources and interests sheds light on one of the axes of this special issue, as it constitutes an institutional and governance challenge for the implementation and expansion of social welfare programmes.

The concept of universal social protection does not refer to a project limited to low and middle-income countries; it is increasingly recognised that it also concerns high-income ones. This means that all peoples - even if there is a particular commitment to the vulnerableshould be granted across the life cycle basic income security and access to essential social services so as to enable them develop their capabilities and make choices about their lives and futures. The core content of universality then includes three elements: availability (sustainable social protection mechanisms must be in place); adequacy (in amount and duration for everyone to realise his/her rights); accessibility, which means, among other requirements, "that States pay special attention to developing programmes based on the principles of nondiscrimination and equality, in particular gender equality, recognition of those workers who tend to be inadequately protected (i.e. part-time, casual, self-employed and home workers) as well as those working in the informal economy, and members of vulnerable or marginalized 
groups, including indigenous peoples, minority groups, non-nationals, internally displaced persons, and internal migrants" (de Schutter and Sepúlveda, 2012).

The point is that while the stated normative aims of universalistic approaches to poverty, social inequalities and injustices - advancing a better and healthier life in dignity for all, enhancing the resilience and capabilities of the destitute, rebuilding strengthened, more cohesive societies less subject to shocks - are clearly laudable, do the policy implementation schemes actually achieve or even come close to achieving these desirable ends? If in praxis the aims translate into mere bricolages - instruments, recommendations and actions fitted to the constraints of what is given-"universalism" is reduced to a managerial instrument emptied of the positive transformational commitment to human development implied by the normative aims.

These questions underpinned a qualitative research programme undertaken by the author and her assistant researcher in Greece 2017-2019 on the implementation of two universal schemes introduced in the country in 2017. First, a general minimum income (GMI)-rebranded in 2016 Social Solidarity Income (SSI), and again GMI in January 2021 (both acronyms are used interchangeably) _, which is a "general household assistance" programme, entailing regular cash benefits to households identified as poor (in Greece, extreme poor). GMIs are a variant of four main social cash transfer instruments (alongside family allowances, conditional cash transfers and social pensions) perceived to best facilitate economic growth by the international organisations (IOs) that have been advocating and financing cash transfer mechanisms in the global South since the early 2000s (Gliszczynski, 2015). Second, Greece devised a scheme aimed at establishing universal health coverage (UHC). Law 4368/2016 allowed all citizens legally settled in the country to access public healthcare by simply presenting their social security number, a measure complemented in 2017 by the formation of a unified network or primary healthcare (PHC). For reasons of space, I have left out universal healthcare (object of a separate paper).

The research was undertaken between June 2017 and November 2019 in Athens and in a nearby working-class municipality hard hit first by a long phase of deindustrialisation, and thereafter by the still more harmful Great Recession of the 2010s. Data relating to the GMI were gathered in the municipality through iterative field observations at the social services (altogether 2 months in 2018) and 43 semi-structured (sometimes serial) interviews (in Greek) throughout the period with mayors and the municipal staff, with NGO workers, community activists and local agents engaged in solidarity structures (such as food distribution and defence of over-indebted people), with beneficiaries and precarious working non-beneficiaries (snowball method), and with a few national level agents ( 2 central managers, one deputy minister, one expert from the WB). Interviews were usually face-to-face, mostly involving the two researchers. I also relied on a desk review of IOs' reports, on primary and secondary sources and on macro-statistical indicators.

The approach is critical grounded theory, a methodology that combines critical realism, cultural political economy and grounded theory (e.g. Oliver, 2012; Belfrage and Hauf, 2017). Given "that texts circulate without their context, that they do not carry along the field of production of which they are the product" (Bourdieu, 2002), I initially left in the background the knowledge acquired through readings on USP and previous research related to social protection policies in the broader context of neoliberal governementality (Foucault, 2004). The aim was to explore the Greek case as openly as possible, using the tools of grounded theory (coding, memoing, constant comparison, theoretical sampling) to allow for emerging analytical and interpretive processes without forcing the data collected into preconceived categories. 
The epistemic stance is not one of axiological neutrality: as Bourdieu (2000) notes, the knowing subject cannot achieve the "objectivism of the distant gaze of an observer who remains as remote from himself as from his object" and cannot be asked to "build science on something as poor as ethical neutrality" (2015, p. 67). "Reality" is socially constructed (e.g. Charmaz, 2009; Oliver, 2012; Belfrage and Hauf, 2017). Moreover, critical grounded research is always driven by an emancipatory ambition - emancipation meaning "the transformation from an unwanted and unneeded source of determination to a wanted and needed one" (Bashkar, 2009, pp. 138-139). The initial research question was thus to determine whether or not the introduction of USP mechanisms was likely to enable such a transformation, if only partial or potential, in people's lives. "Universality" emerged from the research process as a core analytical category linking global and local "pro-poor" policies. Yet the category requires conceptual clarification since it encompasses different understandings and implications: a positive commitment to human development in a human rights perspective (ILO/UN) on the one hand, or a reductive approach that is merely a reworked version of labour market activation policies, on the other.

I focus on the latter problem. This work is necessarily limited in scope and breadth. Refugees, women and the homeless are not the subject of a specific analysis, though they disproportionately belong to extreme poverty categories. Likewise, on the global level the analysis is focused on the World Bank because of its hegemony (e.g. Gliszczynski, 2015; Merrien, 2013) in the field of global social policy and its role in setting the Greek GMI (for a more wide-ranging discussion on IOs' engagement in USP, see Shriwise et al., 2020). For reasons of space, I have left out universal healthcare (object of a separate paper). The study does not provide extensive background material related to the evolving architecture of European welfare regimes or the underlying political, economic and administrative dimensions of the Greek minimum scheme, which has already been valuably investigated by other researchers and experts.[1]

The article proceeds as follows. The next section provides a definition of universality as it emerges from the evolution of European, WB and ILO normative views. It then turns to consider the "modernisation" of the Greek social welfare system through the introduction of cash transfers. This section emphasises the relationship between the level of benefits and informal work, as well as the tension between universality and targeting mechanisms. Findings are discussed in the last concluding section.

\section{Marketing universality}

The new consensus on global social policies crossed continents. Although Europe seemed to follow a sui generis path, it was part of the process. Starting in the 1980s, member states' post-war social protection systems were gradually recommodified-cost-containedrecalibrated (Pierson 2002). Post-war welfare rights were weakened and minimum "universal" (means-tested) social cash transfers and in-kind benefits introduced in an effort to streamline social protection systems, "fill their holes" and make them more "efficient". The uneven, gradual, and yet unfinished construction of a "minimal European social state" (Burgi, 2009) underpinned the conceptual rapprochement between the EU and WB-led global social policies. Notwithstanding considerable intra- and inter-regional differences, European and global assumptions regarding social protection converged under the headings of "social investment" and "universality".

Social investment and universality are two sides of the same coin: the former qualifies the latter. The idea of a "social investment state" is to reduce the coverage gap between protected "insiders" and a growing number of unprotected "outsiders" left on the margins of post- 
industrial labour markets, through human capital investment in population categories that promise to have the most impact on economic growth in the future: in children to break the cycle of poverty transmission, in women and, beyond that, in the marginalised fractions of society that lack the resources to cope with hardship and "new risks" (Jenson and SaintMartin, 2003.). Social investment involves an activation regime that promotes labour market participation, but the concept allows for different interpretations. Anthony Giddens (1998) argues for a shift from passive to active social policies, while the now prevailing perspective developed Gøsta Esping-Andersen and others, including the WB and EU, calls for a strategy of both protection and investment, the latter not being a substitute for the former. From this point of view, basic minimum income protections (unconditional "passive" benefits) are still needed to reduce poverty because it is intergenerational and hinders growth (EspingAndersen 2002; Esping-Andersen et al. 2001).[2]

The concept seems to match the notion of Social Protection Floors (SPF) - an ILO initiated strategy enshrined in ILO (2012b) Recommendation 202 endorsed by most development institutions (including the WB, which partnered with the ILO in 2015). Floors are "nationally defined sets of basic social security guarantees which secure protection aimed at preventing or alleviating poverty, vulnerability and social exclusion". The European Pillar of Social Rights initiative (2017) aims to guarantee European-wide basic "principles and rights" for the most needy. In both cases the idea is to protect the poor, and to achieve a higher degree of universality if, when and where possible by also covering better-off groups (ILO 2012a, 2012b).

There is, however, an important difference in the ILO/UN and WB approaches. The first is based on "standing, rights-based, social protection floors, defining beneficiaries as rightsholders with entitlements they may claim" (De Schutter, 2020), whereas the second focuses on social risk-management. The WB and increasingly the EU see floors as the substructure of "universal social protection" systems in which different types of public, private or community based schemes protect different groups against specific risks over the life course (WB, 2009a). The WB risk management approach assumes that state institutions in developing countries (or in highly indebted European "peripheral" countries such as Greece) can only provide the most limited forms of social protection. Public spending on social security should therefore be kept to a minimum, while risk management should be first and foremost the responsibility of individuals and families, and then of communities.

The ILO sought to create a Global Fund for social protection to finance Floors in poorer countries, an initiative put forward by the SPF Advisory Group in its 2011 Report (ILO, 2011) and later strongly advocated by UN Special Rapporteurs Olivier de Schutter and Magdalena Sepúlveda (2012). But the "emphasis on global funding withered during the course of the passage of the Recommendation... which at the end says only that 'national social protection floors should be financed by national resources', while countries 'whose economic and fiscal capacities are insufficient to implement the guarantees may seek international cooperation and support that complement their own efforts" (Deacon (2013, p. 57). The global fund idea has resurfaced since COVID-19 and steps have been taken to temporarily support recovery and social protection (De Schutter, 2020). The efficacy of these emergency measures remains to be seen. What can be said is that the international institutional balance has so far been unfavourable to a robust appreciation of Floors. Dominant understandings of the IOs "have narrowed in ideational and instrumental terms since the 2008 global financial crisis" and the ILO's 2012 Recommendation, and tend to be reduced to cash transfers and poverty alleviation (Shriwise et.al, 2020).

The question arises whether these programmes, however insufficient, offer a decent solution to incoherent, fragmented and unjust social protection systems such as the Greek one prior to 
2010, and to the problems Greek society has faced since the exogenously-induced depression of the 2010s (a collapse of GDP of great amplitude, rare in peacetime conditions).

\section{Greece's frail and imbalanced welfare}

On the eve of the first memorandum of understanding (MoU) (2010) the Greek labour market and welfare system were polarised between a fairly well insured core workforce and a "periphery" of weakly or uninsured precarious labourers. This typical feature of the southern European social protection model was not rudimentary, but it was unfair, often wasteful, displaying wide coverage gaps. Consequently, social cohesion depended heavily on family solidarity and on public sector jobs: because the latter offered employment stability and better pensions than the private sector, they represented a functional substitute for inadequate social protection, social and territorial inequalities, scarce social assistance and chronically insufficient job creation. The framework was one of fragile structural balances that allowed the society to "hold on" as long as employment was available (e.g. Ferrara, 1996; Petmesidou and Mossialos, 2006; Papadopoulos and Roumpakis, 2013) .

Greece's mixed regime of state-protected and family welfare was ill-prepared to withstand the labour market changes induced by the competitve logic of global capitalist transformation in the 1990s and 2000s. It was even less prepared to weather the "internal devaluation" shock imposed on the country from the inception of the first MoU by means of frontloaded wage cuts, tax increases, suppression of demand, very significant cuts in public spending including vital local or national healthcare and other services, as well as measures such as labour market deregulation and weakening of trade unions, all of which led to skyrocketed unemployment, steep declines in living standards, household over-indebtedness, divorces, domestic violence, bankruptcies, low-cost drug abuse, serious mental and physical illnesses, and so on (e.g. Laskos and Papadatos-Anagnostopoulos, 2020; Burgi, 2014).

In the face of the social breakdown, there is no question that another system was urgently needed. Some authors argue that "the extent of waste and inefficiency in the use of resources... suggested that that the scope for strengthening social protection while cutting social expenditure was considerable" (Matsaganis, 2011; 2020 [quote]), and indeed governing Institutions (the IMF, ECB and EC troika) moved in that direction. The second December $2012 \mathrm{MoU}$ called for the introduction of a minimum income guarantee scheme from 2014 onwards alongside "savings from rationalisation of social benefits" (European Commission, 2012 pp.251-252 [quote]; IMF, 2012, p. 20). Because of the political, economic and social turmoil-and no doubt because social protection never figured in the MoUs as a "key deliverable" - the national rollout of the SSI did not happen before February 2017 (after being pilot-tested twice in 2014-2015 and in 2016). However, the WB was brought in as early as 2013 to provide technical support to the development and implementation of the project. It designed the Greek scheme, monitored its implementation and was, according to our interviews, "very pushy", directing the operations to make sure the program conformed to the prescribed model, "putting heavy demands on a system that was not working the way it wanted it to, that had no infrastructure."

The new universal solidarity income streamlined welfare (and cut social expenditure, see e.g. INE/GSEE 2020), but did it protect the most vulnerable part of the Greek population? Two relevant parameters are examined below. First, the level (or "generosity") of allowances granted to beneficiaries and the alleged "springboard" effect (WB, 2011), if any, of the scheme - that is, whether or not the poor will be in a position to become (future) "risk-takers" in the market. Second, population targeting patterns and processes for the distribution of cash 
transfers, since targeting practices determine the substantiation of rights, and thus what is meant by universality (Cruz-Martínez, 2020).

\section{The amounts of cash transfers}

The GMI includes a regressive allowance (the so-called Pillar 1) slightly lower than the extreme poverty threshold[3] not exceeding €200 monthly for a single person, and for example $€ 400$ for a family of four or $€ 500$ for a couple with four minor children. It also includes (Pillar 2) in-kind social benefits (food distribution, discounts on electricity bills, access to public healthcare) and job-seeking assistance (third Pillar). Eligibility thresholds are very restrictive. The household's income during the six months preceding the application must not exceed six times the amount of the allowance (e.g. 1,200 for a single person, a little more dependent on the composition of the household, for example 3,000 for a couple and four children). There are additional criteria for ownership, which also vary according to the size of the household. They include the taxable value of real estate in Greece or abroad ( $€ 90,000$ for a single person, with a ceiling fixed at 150,000 at the time of the survey), the objective value of all types of private vehicles, including bicycles (the total amount must not exceed $€ 6,000$ ), and total bank or cash deposits (€4,800 for a single person, €9,600 for two adults and two minor children, $€ 14,000$ for two adults and six minor children, with intermediate ceilings referring to the composition of households). Implementation of the scheme is entrusted to the municipalities.

Most researchers and experts note that income transfer levels and access requirements of the scheme are very stringent. Even the WB (2019a) evaluation admits as much, stating "that most SSI beneficiaries would not make it over the poverty line". Indeed, according to the Bank's survey data, poverty before and after benefit intake is only reduced from $15.2 \%$ to $14.4 \%$. What does this result imply? Whereas cash transfers are supposed to counteract poverty, are the programme's aims poverty reduction (of the number of poor) or alleviation (diminution of the poverty gap, that is, the average distance from the poverty line)? As Gliszczynski (2015, p. 33) points out, the undifferentiated use of the two expressions in many global policy documents is misleading. His close analysis demonstrates "a tendency towards poverty alleviation as a goal of cash transfers, especially the most severe forms of poverty". In the case of Greece, this is indeed the objective (the poverty gap falls by almost 2 percentage points nationwide according to WB estimates), meaning - as in the case of many countries in the global South - that the fight against extreme poverty is narrowed down "to securing an absolute minimum level of consumption for the poor, emphasising the existential minimum of nutrition" (ibid.).

This absolute minimum does not constitute a paradigm shift, as some authors have argued. As Foucault emphasises, the thoroughgoing social transformation sought by the neoliberal project consists in establishing competitive mechanisms as the "general regulator of society to which all [including government] are submitted and should be willing to comply to", and that the only exception would be what he called a "safeguard clause" (clause de sauvegarde) or "non-exclusion" rule enforced by the state in favour of people situated below an "absolute poverty" line (e.g. extreme poverty lines). In other words, the safeguard clause would be an exception to freedom from state interference: only in cases of extreme poverty should a community grant a subsistence minimum protecting individuals from elementary physical needs in order to safeguard their health and capacity to work. The exception only addresses the effects, not the causes of poverty and inequality (Foucault, 2004, pp. 207-2013; Burgi, 2006, pp. 141-150; Crouch and Keune, 2012). 
In this light, it is doubtful whether absolute minimum cash transfers are likely to empower the poor and enhance their capabilities. However, GMI pillars 1 and 2 (monetary support, and inkind social benefits) are meant to be complemented by a third pillar designed to "activate" the poor into the labour market, which is believed to offer the best protection against hardship.

\section{Activation and the question of informal work}

At the time of our investigation, "activation" encompassed a few public employment programmes for which minimum income recipients were granted priority access. They included vocational training and other labour market programmes such as low-wage full time (around $€ 500$ monthly) or reduced working hours fixed-term contracts (usually nonrenewable eight month contracts) in municipalities. [4] This is standard public policy strategy for handling queues of unemployed people. At the end of the contract, people have to wait six months or more before applying again for SSI or another unemployment service (OAED) programme. According to a municipal employee, the underlying logic of long delays without resources is "that s/he could have saved up for another six months" during the assisted job.

The idea that "activation" might be the appropriate solution to poverty has deeply penetrated people's minds by dint of reiterated political, managerial and moralizing discourses stigmatizing the alleged idleness of jobseekers. The young social workers we met at the end of 2018 in the community centres were inclined to think that the recipients were resting on their laurels. They expressed hope for the announced introduction of back-to-work schemes. When asked if there were jobs, they would keep silent. We also observed over time a change in attitude of a municipal employee whom we met repeatedly from the beginning to the end of our survey. She was initially rather doubtful that the amounts allocated would allow for anything other than survival, and ended up believing that poor people were responsible for their fate. At the same time, however, she never departed from the conviction that the recipients in their majority "work under the table" because, she repeatedly told us, they are "forced to do so". The central manager responsible for regulating the national scheme had converging assumptions. After statements such as:

The objective is inclusion. The problem for many people is not poverty per se, but the fact that they cut themselves off from society.

he admitted that SSI recipients were likely more often than not to be offered $€ 250$ part-time positions (if any) and that neither such underpaid jobs nor the allowance, which is slightly lower, are enough to live on.[5]

Notwithstanding a minority that tries to game the system to get the allowance on top of enough personal revenues or savings, working on the side is protective given that the ability to benefit from activation labour market programmes is unevenly distributed and generally inefficient in the case of GMI recipients. For the most vulnerable, make-work-pay GMI activation policies are a "sham" (Burgi 2006), a "dogma" (Peña-Casas and Bouget 2014). Obsession with benefit fraud in the public debate sustains that "dogma". As Ramón PeñaCasas and Denis Bouget argue in their comparative analysis of GMIs in Europe, "the fear that GMI will act as a deterrent, discouraging recipients from returning to work" is based on "an oversimplistic comparison between the level of benefits and that of low wages". What is the point of "vaunting the social effectiveness of incentivising activation policies" when lowpaid jobs "are not sufficient in themselves to provide a road out of poverty" (ibid., pp.138-140; see also Cantillon et al., 2020)? Therefore, it can be assumed that one reason why GMI recipients may and do tell interviewers or evaluators (WB, 2019a) that the program has a beneficial effect in their lives is linked to the hazardous possibilities of the informal market.[6] With a small income supplement, the SSI functions as an extremely basic monetary protection that 
also includes free medication, maybe a meagre housing benefit and $75 \%$ reduction on electricity bills. For most recipients, undeclared work does not, however, eliminate the day-today struggle for survival (all the more so in acute life-threatening periods such as the current pandemic).

Further research, including qualitative studies, is needed to take full account of the size, causes and consequences of the shadow economy (Almenar et al., 2020; Medina and Schneider 2018), notably to assess how it is driven by but also fuels social vulnerability. Global agencies such as the WB do not outright condemn undertakings in the informal sector-defined as labour and business that is hidden from monetary, regulatory, and institutional authorities. The Bank considers that the sector may be an "engine of growth", that it "can serve as buffers and safety nets for the poor if it absorbs labor during recessions" (WB, 2019b). In India - one among many other illustrations found in the Bank's reportlinkages between formal and informal sectors, or formal and informal sector employment are thought to be positively correlated, "for example when subcontracting by formal-sector firms to informal firms contributes to job creation in the informal sector" (ibid.).[7]

Considered an "engine for growth", informal employment becomes a tolerable complement to devices such as public work programmes (or workfare for that matter), which are a strong alternative model to unconditional cash transfers for the poor (Gliszczynsiki, 2015). In sum, the WB approach according to which poor people "adapt" to structural adjustment shocks and "are willing to work for low wages" implies that low-paid, precarious jobs offered through public programs or the informal market (depending on circumstances) are viewed as a "useful" and inexpensive "countercyclical instrument for reaching poor unemployed workers" because they can "easily be self-targeting by paying wages below market rates" (WB, 1990). In this perspective, universal welfare for the poor entails, to quote Jamie Peck's (2001) rather provocative formula, "McJobs" plus "McWelfare".

\section{Targeting patterns and processes}

The substance of universality may also be examined in the light of targeting processes. Means-tested schemes involve specific managerial technologies captured by the idea of "individualised mass management". The seemingly contradictory terms qualifying this approach-mass ("universal") management that is simultaneously individualised - reflects a classic problem for all means-tested devices: how is individualisation subsumed under a supposedly universal category? Individualisation subdivides the universal into categories and sub-categories with porous and evolving contours - e.g. alimony recipients, students, young people, the military, the homeless, the self-employed, employees, pensioners, the disabled, the Roma, "foreigners", refugees, etc. Where is the common measure that allows for individualisation in the context of universalised mass management? This conceptual problem is at the root of difficulties encountered at both national and local levels. While national authorities count on technology, local officers devoted to their public service mandate, faced with real people and real situations, encounter moral and practical dilemmas.

GMI applications are carried out through a computer programme capable of cross-referencing online data, that is, verify and validate information through several electronic platforms and identify the applicant through the tax return system. This kind of platform did not previously exist in Greece. It has been designed to be intuitive to facilitate its use by any person wanting to process an application - civil servants, temporary workers recruited during peak periods, accountants, ordinary citizens. The platform is constantly updated to incorporate knowledge (other online data, errors or failures detected through regular inspections, information from municipalities, evaluations, seminars, and so on). National officers rely heavily on this 
technology while recognizing some limits to its capacity to identify the exact situation and composition of any given household: it would almost require "doing a survey in each house", a central officer told us.

Even though the GMI platform functions rather smoothly, mismatch situations between welfare-seekers' accounts and online information often occur. In such cases, social workers have the choice whether or not to further investigate. Cross-checking information is not necessarily an easy task. Employees can contact the Ministry of Labour, Social Insurance and Solidarity (hereafter referred to as "the Ministry") directly at the risk of having to do so several times and getting different answers each time. Alternatively, they can ask the applicant to provide supporting documents, but they might not know what to ask for. "It could be thousands of things", said a local administrator. "Everyone's knowledge is different. Even the Ministry is not familiar with this bureaucracy." Most caseworkers do not even know how to read and understand tax returns. Under urgent pressures, understaffed municipalities had assigned the first available person to case-management and provided summary training to merely operate the computer programme. As a result, caseload management practices differ greatly from one social service to another. We observed that temporary recruits as well as some social workers tended to apply whatever comes out of the computer programme.

The margin of error of the information system in determining eligibility is quite large and introduces arbitrariness. "It is very easy to [unfairly] reject more than half the applications simply on the basis of what appears on the platform", a municipal officer told us. Whether they err in favour of a non-eligible person, or unjustly dismiss another person's case, public agents are covered and have a great deal of discretionary power. In contrast, applicants are held responsible for any mistakes that may appear in their file, even if someone else was at fault. Since a large proportion of applicants are sick and uneducated,[8] this is among many injustices that mass micro-management produces.

The World Bank (2019a) describes the SSI as "the first means tested program in the country targeting explicitly extremely poor households solely on the basis of their poverty status and without categorical exclusions". We observed, however, that all inhabitants do not have the same rights. Targeting mechanisms include or exclude people from social welfare according to complex (and changing) criteria that are supposed to tailor the presumed universality of the programme to individual situations. Eligibility rules exclude "alien" non-citizens, such as undocumented migrants, "unprocessed" refugees and what woud translate as "non-resident residents". The latter are people who had been living in the country for at least five years at the time of our study (the government's temptation is to extend the requirement to twelve years) but could not prove it. They had yearly renewable residence permits but only had their last permit, which is deemed invalid for proof of five-year residence (some municipalities managed to solve the problem by turning to the Ministry, others failed to do so). Likewise, registered refugees have access to the scheme if they have a residence permit and a permanent address. If they do not but live in a squat hotel, for example, they can declare themselves homeless, but then they need a certificate of homelessness. The latter may be issued after a "sociological investigation" in which a social worker must verify if the refugee is always at the same place on the street. We know cases of refugees who had to spend whole days outside for that purpose (one of the researchers had access to the refugee squat hotel City Plaza).

Other targeting mechanisms introduce arbitrary differences between recipients. Soldiers who return to live with their families are not included in the household composition (this reduces the domestic allowance by $€ 100$ ) because it is deemed that the state supports them (till 2019, the majority were paid $€ 8,80$ per month). [8] Students do not have access to the SSI if they live away from their parents. The overlapping of solidarity income and a $67 \%$ disability allowance paid by the state is allowed, whereas it is not allowed for disability pensions 
covered by insurance funds. Child allowances ( $€ 70$ per child, $€ 100$ for a single-parent family with one child) cannot overlap with the SSI. If a woman's ex-spouse does not remit due alimony (usually between $€ 200$ and $€ 300$ depending on his income), which frequently happens, the authorities consider the money to have been given to her in cash. She is then excluded from the scheme because her theoretical income no longer meets eligibility criteria. It goes without saying that these and other inequalities inevitably feed the search by recipients for ways to adapt to the required criteria in order to increase their benefits.

Successful adaptation is called resilience, which has become an increasingly important component of public policy discourse. Resilience is not akin to capacity building: it accommodates the world as it is, asking people to conform to constraints and to adapt in the face of durable social difficulties. While capacity building seeks to address causes, the promotion of resilience merely addresses effects. The concept has colonised political imagination and institutional thinking, becoming a substitute for truly transformative social projects. In this shrinking of the social imagination, broader social justice aims are set aside: the fight for inclusion and fairness is replaced by resilience building (WB, 2019c).

\section{Concluding remarks}

Drawing on our Greek GMI study_-GMI being an key component of USP_-, this article sought to engage in a critical examination of the meaning and substance of universality, the normative aims of which refer discursively at times to human rights and at other times more prosaically to the creation of new market actors. In both cases, the fight against poverty and "empowerment" of the "vulnerable" is the issue at stake.

The abstract promise of USP has proved elusive. Broadly speaking, compared to Greece's previous unbalanced welfare regime, the effort to streamline social protection through a "universal" minimal social safety net slightly reduced inequality and alleviated extreme poverty. The GMI, however, is not up to the challenge. World Bank statistics show that Greek GDP per capita in current international dollars fell continuously and sharply from 2008 $(31,997$ current US dollars) to $2015(\$ 18,167)$. This was followed by a slight but incomplete recovery in $2018(\$ 20,324)$ and a new decrease in $2019(\$ 19,582)$ or $29 \%$ less than in 2008. The late 2010s stabilisation occurred at very low levels. Despite a decline of the number of people at risk of poverty and social exclusion, poverty indicators remained high and the European 2020 strategic objective to reduce the number of people at risk of poverty or social exclusion in Greece by 450,000 did not materialise (the number actually increased).[9] Conditions are bound to get worse as a result of the 2020 economic and social recession caused by COVID-19.

Our fieldwork complements these macro-statistical indicators and shows that policy programmes and measures implemented by the EU, the international institutions and the Greek government have not generated the conditions for substantive improvements of people's lives since they involve adaptations to current degraded socio-economic conditions rather than their transformation. This is a particularly pronounced problem in Greece, as in other "weak" states that lack infrastructural power (Mann, 1993). Large but differentiated vulnerable populations are not being given the means to live decent and meaningful lives, the cash transfer and other mechanisms being tailored to other purposes. Strengthening work incentives and enhancing controls over recipient's lives, advocated by the authorities and some academics (e.g. Matsaganis, 2020), cannot be considered a sustainable way forward: they are managerial technologies not tools of human development. The suddenly discovered virtues of the informal sector as an "engine for growth" is likewise part of the adaptive logic 
adopted by international and EU expertise (after consistently unsuccessful and damaging structural adjustment programmes).

From a normative social justice standpoint that seeks to enhance people's effective freedoms to act as self-determining agents, current universal programmes fail to fulfil their stated aims and promise. They do not protect people from the hazards of life, from shocks over which they have no control. In Greece, people face over-indebtedness, evictions and forced home auctions for unpaid taxes, property charges or any other debt, and objective reductions of access to public health services, among other life problems. The international institutions and the EU apparently see no contradiction in downsizing the national health system, which was shrunk considerably through the various MoUs since 2010, and then legislating to give everyone free access to overloaded, understaffed, scaled-down public health services (Burgi, 2018; Petmesidou, 2019). "Access alone", an infectious disease specialist told us, "is like being told that I'm giving you a free pass to all the buses in the country, except that there are no buses outside".

\section{Notes}

[1] There is a substantial literature on the development of the Greek social state and now on the GMI-SSI. See for example Dimoulas, 2018; Lalioti 2016a, 2016b; Matsaganis, 2020, 2011; Petmesidou and Glatzer, 2015; Petmesidou et al., 2014; Petmesidou and Mossialos, 2006; Sakellaropoulos et al. 2019; Sakellaropoulos et al., 2018; WB 2015, 2019a.

[2] It remains that the predominantly pejorative representation of "passive" benefits tends to frame the welfare public debate around issues relating to individual behaviours and their willingness to adjust to what is given, a view that may lead to shifting responsibility for their situation to the poor and unemployed (despite the fact that the social investment approaches presupposes that the poor are not responsible for their fate). The focus of social investment is ultimately on the supply side (Jenson, 2008), and critical research, including in Northern European countries, has shown that gender implications and labour market conditions tend to be ignored (e.g. Jenson, 2008, 2009; Mitdbøen and Teigen, 2014).

[3] Following Matsaganis et al. (2016), extreme poverty in Greece refers to a poverty threshold the level of which $(€ 233)$ is estimated from the cost of a consumer basket with a minimum of basic products at constant prices and varies according to the area under consideration and the composition of the household.

[4] On recent developments in activation policy and programs, including basic sociological characteristics of beneficiaries, see Ministry of Labour GMI Monitoring Report on KEA applications (September 2019) https://kekpa.gr/el/ypiresies/98-koinoniko-eisodima-allileggyis-k-e-a/2935-enimerosi-gia-kea-epidoma-stegasis (in Greek).

[5] INE/GSEE (2019) reports that $29 \%$ of private sector workers had an average wage of $€ 375.53$ in 2018 ; $25.3 \%$ were paid less than $€ 500$ and $11.1 \%$ below $€ 250$ (https://www.inegsee.gr/ekdosi/etisia-ekthesi-2019-inegsee-i-elliniki-ikonomia-ke-i-apascholisi/).

[6] The size of the informal economy in Greece overall has been estimated around 27-30\% percent of GDP (Medina and Schneider, 2018, ILO 2017). There is a lack of reliable databases.

[7] In India—one among many other illustrations found in the Bank's report-linkages between formal and informal sectors, or formal and informal sector employment are thought to be positively correlated, "for example when subcontracting by formal-sector firms to informal firms contributes to job creation in the informal sector". According to the WB, informality as an "engine for growht" entails policy implications ranging from no policy response to measures "to ease labour rigidities" (WB, 2019b).

[8] http://www.ellinikos-stratos.com/thiteia/misthos.asp. The pay was increased in 2019 but was still under $€ 100$.

[9] https://ec.europa.eu/eurostat/databrowser/view/t2020_50/default/table?lang=en.

\section{References}


Almenar V., Sánchez J.L., and Sapena J. (2020), "Measuring the shadow economy and its drivers: the case of peripheral EMU countries",Economic Research-Ekonomska Istraživanja, Vol. 33, N¹, pp.2904-2918.

Belfrage, C., and Hauf F. (2017), "The Gentle Art of Retroduction: Critical Realism, Cultural Political Economy and Critical Grounded Theory", Organization Studies, Vol. 38, $\mathrm{N}^{\circ} 2$, pp.251-271.

Bhaskar, R. (2009 [1986]), Scientific Realism and Human Emancipation, Routledge, London.

Bourdieu, P. (2015), Sociologie générale. Vol 1. Cours au Collège de France 1981-1983, Seuil, Paris.

Bourdieu P. (2012), "Les conditions sociales de la circulation internationale des idées", Actes de la recherche en sciences sociales, Vol. 145, pp.3-8.

Bourdieu, P. (2000) "Participant Objectivation", Huxley Memorial Lecture, Royal Anthropological Institute, London, December 6.

Burgi, N. (2018), "The Downsizing and Commodification of Health Care", Doxiadis E. and Plakas A. (Ed.s), Living under Austerity: Greek society in crisis, Berghan, New York, pp.217-250.

Burgi, N. (Ed.) (2014), La Grande Régression. La Grèce et l'avenir de l'Europe, Le Bord de l'Eau, Lormont.

Burgi, N. (2009), "La construction de l'État social minimal en Europe", Politique européenne, Vol. 27, $\mathrm{N}^{\circ} 1$, pp.201-232.

Burgi, N. (2006), La Machine à exclure. Les faux-semblants du retour à l'emploi, La Découverte, Paris.

Cantillon, B., Parolin S., and Collado D. (2020), "A glass ceiling on poverty reduction? An empirical investigation into the structural constraints on minimum income protections", Journal of European Social Policy, Vol. 30 º2, pp.129-143.

Charmaz, K. (2009), "Shifting the grounds: Constructivist grounded theory methods", in J.M. Morse, P.N. Stern, J.M. Corbin, B. Bowers, and A.E. Clarke (Ed.s), Developing Grounded Theory: The Second Generation, Walnut Creek, CA, University of Arizona Press, pp.127-54.

Crouch, C., and Keune M. (2012), "The goverance beyond the 'new social risks' analysis", Working Paper 2012.03, ETUI, Brussels.

Cruz-Martínez G. (2020), "Rethinking universalism: Older-age international migrants and social pensions in Latin America and the Caribbean", Global Social Policy, Vol. 20 $\mathrm{N}^{\circ} 1$, pp.39-59.

Deacon B., with Hulse M. and Stubbs P. (1997), Global Social Policy: International Organizations and the Future of Welfare, Sage, London.

Deacon, B. (2013), "The social protection floor and global social governance: Towards policy synergy and cooperation between international organizations", International Social Security Review, Vol. 66, N³-4, pp.45-67.

De Schutter, O. (2020), "The Global Fund for Social Protection: an idea whose time has come", Social Europe, November 17, https://www.socialeurope.eu/the-global-fundfor-social-protection-an-idea-whose-time-has-come (Accessed 11.02.2021).

De Schutter, O., and Sepúlveda, M. (2012), Underwriting the Poor: A Global Fund for Social Protection, Briefing Note 07, October. 
Dezalay, Y., and Garth B.G. (2011), "Hegemonic Battles, Professional Rivalries and the International Division of Labor in the Market for the Import and Export of StateGoverning Expertise”, International Political Sociology, N5, pp.276-293.

Dimoulas K. (2018) "Crisis and Social Solidarity Income, in K. Dimoulas, and G. Kouzis (Ed.s), Crisis and Social Policy, TOPOS, Athens [in Greek].

Esping-Andersen G. (2002), "A new European social model for the twenty-first century?", Rodriques, M.J. (Ed.), The New Knowledge Economy in Europe: A Strategy for International Competitiveness and Social Cohesion. Edward Elgar Publishing, Cheltenham, Glos.

Esping-Andersen, G., Gallie, D., Hemerijck, A. and Myles, J. (2001), Why we Need a New Welfare State, Oxford University Press, Oxford.

European Commission (2012), The Second Economic Adjustment Programme for Greece. $\begin{array}{llll}\text { First Review, } & \text { Occasional } & \end{array}$ https://memorandabilia.files.wordpress.com/2016/05/ocp123_en.pdf (last accessed 31.10.2020).

Ferrara, M. (1996), "The Southern 'Model' of Welfare in Social Europe", Journal of European Social Policy, Vol. 6 ํ1, pp.17-37.

Foucault, M. (2004), Naissance de la biopolitique. Cours au Collège de France 1978-1979, Seuil, Paris.

Giddens, A. (1998), The Third Way: The Renewal of Social Democracy, Polity Press, Cambridge.

Gliszczynski, M. Von (2015), Cash Transfers and Basic Scoal Protection: Towards a Development revolution? Palgrave, Macmillan, New York.

Gliszczynski, M. Von, and Leisering L. (2016), "Constructing new global models of social security: How international organizations defined the field of social cash transfers in the 2000s", International Social Policy, Vol. $45 \mathrm{~N}^{\circ} 2$, pp.325-343.

Hemerijck A. (2012), “Two or three waves of welfare state transformation?”, Morel N., Palier B., and Palme J., Towards A Social Investment Welfare State?: Ideas, Policies and Challenges, Polity Press, Bristol, pp.33-60.

Hemerijck A. (2018). "Social investment as policy paradigm". Journal of European Public Policy, Vol. $25 \mathrm{~N}^{\circ} 6$, pp.810-827.

INE-GSEE (2020). The Greek economy and employment. Annual Report. Athens [in Greek].

ILO and World Bank Group (2015), "A shared mission for universal social protection". Concept Note. https://www.ilo.org/wcmsp5/groups/public/---dgreports/--dcomm/documents/genericdocument/wcms_378996.pdf (Last accessed 31.10.2020).

ILO (2017), "Undeclared Work in Greece: Nature, Drivers and Way Forward", Policy Brief Series, $\mathrm{N}^{\circ} 1$.

ILO (2011), Social protection floor for a fair and inclusive globalization. Report of the Advisory Group chaired by Michelle Bachelet". https://www.ilo.org/wcmsp5/groups/public/---dgreports/---dcomm/--publ/documents/publication/wcms_165750.pdf (Last accessed 11.02.2021).

ILO (2012a), The strategy of the International Labour Organization. Social security for all: Building social protection floors and comprehensive social security systems. 
https://www.ilo.org/wcmsp5/groups/public/---ed_protect/---

soc_sec/documents/publication/wcms_secsoc_34188.pdf (last accessed 31.10.2020).

ILO (2012b), "R202: Social Protection Floors Recommendation, 2012 (N²02)." 101st International Labour Conference session. https://www.ilo.org/dyn/normlex/en/f?p=NORMLEXPUB:12100:0::NO::P12100_ILO _CODE:R202 (last accessed 31.10.2020).

IMF (2012), Country Report $\quad \mathrm{N}^{\circ} \quad$ 12/57. https://www.imf.org/external/pubs/ft/scr/2012/cr1257.pdf (last accessed 31.10.2020).

Jenson J. (2010), "Diffusing Ideas for After Neoliberalism: The Social Investment Perspective in Europe and Latin America", Golbal Social Policy, Vol. 10, N¹, pp.59-84.

Jenson, J. (2009), "Lost in translation: The social investment perspective and gender equality", International Studies in Gender, State \& Society, Vol. 16, N 4, pp.446483.

Jenson, J. (2008), “Writing women out, folding gender: The European Union 'modernises' social Policy », Social Politics: International Studies in Gender, State \& Society, Vol. 15, N², pp.131-153.

Jenson J. and Saint-Martin Denis (2003), "New Routes to Social Cohesion? Citizenship and the Social Investment State", The Canadian Journal of Sociology / Cahiers canadiens de sociologie, Vol. $28 \mathrm{~N}^{\circ} 1$, pp.77-99.

Kanbur R. and Vines D. (2000), "The World Bank and poverty reduction: past, present and future", Gilbert C.L. and Vines D. (Ed.s) The World Bank: Structure and Policies, Cambridge University Press, New York, pp.87-107.

Lalioti, V. (2016a), "The Curious Case of the Guaranteed Minimum Income (GMI): Highlighting Greek 'Exceptionalism' in a Southern European Context', Journal of European Social Policy, Vol. 26, №1, pp.80-93.

Lalioti, V. (2016b), "Guaranteed Minimum Income 'à la Grecque': The Chronicle of a LongAwaited Scheme”, Social Cohesion and Development, Vol. 11, №2, pp.123-138.

Laskos, Ch. and Papadatos-Anagnostopoulos, D. (Ed.s) (2020), Syriza in Power: The Left? Topos, Athens [in Greek].

Mann, M. (1993), The Sources of Social Power: The Rise of Classes and Nation-States, 1760-1914, Cambridge University Press, Cambridge.

Matsaganis, M. (2011), Social policy in hard times: Economic crisis, budgetary austerity and social protection, Kritiki, Athens [in Greek].

Matsaganis, M. (2020), "Safety nets in (the) crisis: The case of Greece in the 2010s, Social Policy and Administration, Vol. 54, pp.587-598.

McKinnon, R. (2004), "Social risk management and the World Bank: Resetting the 'standardes' for social security?”, Journal of Risk Research, Vol. 7, º3, pp.297-314.

Medina L., and Schneider F. (2018), "Shadow Economies Around the World: What Did We Learn Over the Last 20 Years?", IMF Working Paper WP/18/17, https://www.imf.org/en/Publications/WP/Issues/2018/01/25/Shadow-Economies-

Around-the-World-What-Did-We-Learn-Over-the-Last-20-Years-45583 (Accessed 30.1.2021) 
Merrien, F.X. (2013), "Social Protection as Development Policy: A New International Agenda for Action", International Development Policy, Vol. $4 \quad \mathrm{~N}^{\circ} 2$, https://journals.openedition.org/poldev/1525.

Mitdbøen, A.H., and Teigen,M. (2014), "Social Investment in Gender Equality? Changing Perspectives on Work and Welfare in Norway, NORA-Nordic Journal of Feminist and Gender Research, Vol. 22, N 4 , pp.267-282.

Oliver, C. (2012), "Critical Realist Ground Theory: A New Approach for Social Work Research”, British Journal of Social Work, Vol. 42, pp.371-387.

Papadopoulos T., and Roumpakis A. (2013), "Familistic welfare capitalism in crisis: Social reproduction and anti-social policy Greece", Journal of International and Comparative Social Policy, Vol. 29 N³, pp.204-224.

Peck J. (2001), Workfare States, The Guilford Press, New York.

Peña-Casas R. and Bouget D. (2014), "Towards a European minimum income? Discussions, issues and prospects", Natali D. (Ed.) Social developments in the European Union 2013, ETUI, pp.131-159. https://www.etui.org/publications/books/socialdevelopments-in-the-european-union-2013 (last accessed 31.10.2020).

Petmesidou, M. (2019), "Challenges to Healthcare Reform in Crisis-Hit Greece", E-Cadernos CES, Vol. 31, pp.19-42.

Petmesidou, M. (2017), "Welfare Reform in Greece: A Major Crisis, Crippling Dept Conditions and Stark Challenges Ahead", Taylor-Gooby P., Leruth, B., and Chung, H. (Ed.s), After Austerity: Welfare state transformation in Europe after the great recession, Oxford university Press, Oxford, pp.155-179.

Petmesidou M., and Glatzer M. (2015), "The Crisis Imperative, Reform Dynamics and Rescaling in Greece and Portugal", European Journal of Social Security, Vol. 17 N², pp.158-181.

Petmesidou, M., and Mossialos, E. (Ed.s) (2006), Social Policy Developments in Greece, Routledge, London.

Pierson, P. (2002), "Coping With Permanent Austerity Welfare State Restructuring in Affluent Democracies", Revue Française de Sociologie, Vol. 43, N², pp.369-406.

Sakellaropoulos Th., Lalioti V., and Kourachanis N. (2019), The social impact of the "Social solidarity income' in Greece: A qualitative interpretation", Social Cohesion and Development, Vol. 14, $\mathrm{N}^{\circ} 1$, pp.5-20.

Sakellaropoulos, Th., Oikonomou, Ch., Skamnakis, Ch., and Aggelaki, M. (2018) (Ed.s), Social Policy, Dionikos, Athens [in Greek].

Shriwise, A., Kentikelenis A.E., and Stuckler D. (2020), "Universal Social Protection: Is It Just Talk?", Sociology of Development, Vol. 6, N¹, pp.116-144.

World Bank (2019a), A Quantitative Evaluation of the Greek Social Solidarity Income. World Bank, Washington DC.

World Bank (2019b), Global Economic Prospects. Darkening Skies. World Bank, Washington DC.

World Bank (2019c), “Adaptive Social Protection”. World Bank SPJ Core Courses. World Bank,

DC. http://pubdocs.worldbank.org/en/836361575490788719/SPJCC19-SSN-D7S1-BowenAdaptive-SP.pdf (last accessed 31 October 2020). 
World Bank (2016), Greece Social Welfare Review. Weathering the Crisis : Reducing the Gaps in Social Protection in Greece. Social Protection and Labor Global Practice. World Bank, Washington DC (last accessed 31.10.2020).

World Bank (2015), Ex ante poverty and fiscal evaluation of a guaranteed minimum income programme in Greece, World Bank, Washington DC. http://documents1.worldbank.org/curated/en/858011467997278402/pdf/97840-WPP147001-Box391494B-PUBLIC.pdf (last accessed 31.10.2020).

World Bank (2009a), Conditional Cash Transfers - Reducing Present and Future Poverty, World Bank, Washington DC https://openknowledge.worldbank.org/handle/10986/2597 (last accessed 31.10.2020).

World Bank (2001) Social Protection Sector Strategy: From Safety Net to Springboard, World Bank, Washington DC. http://documents 1.worldbank.org/curated/en/299921468765558913/pdf/multipage.pdf (last accessed 31.10.2020).

World Bank (1990), World Development Report 1990, World Bank, Washington DC. https://openknowledge.worldbank.org/handle/10986/5973 License: CC BY 3.0 IGO (last accessed 31.10.2020). 